\title{
Knowledge towards antibiotic usage among paramedics and non- medical personnels of a tertiary care hospital
}

\author{
Pranjit Narzaree*, M. C. Gupta
}

Department of Pharmacology, Pt. B.D.Sharma, PGIMS, Rohtak, Haryana, India

Received: 23 June 2016 Accepted: 05 August 2016

\author{
*Correspondence to: \\ Dr. Pranjit Narzaree, \\ Email: drpranjit504@yahoo.com
}

Copyright: (C) the author(s), publisher and licensee Medip Academy. This is an openaccess article distributed under the terms of the Creative Commons Attribution NonCommercial License, which permits unrestricted noncommercial use, distribution, and reproduction in any medium, provided the original work is properly cited.

\begin{abstract}
Background: The aim of this study was to assess the knowledge, selfmedication behaviour and attitudes toward antibiotic usage among paramedics and non-medical working staff of a tertiary care hospital.

Methods: A cross-sectional study was designed using a self-administered questionnaire to access the knowledge, self-medication behaviour and attitude towards antibiotics usages among the two groups of participants from paramedics and non- medical working staff of PGIMS Rohtak administration.

Results: All the participants from paramedics (100\%) were aware of the term antibiotics and antibiotic resistance compared to the non-medical personnels. Non-medical staffs $(86 \%)$ were aware of the term antibiotics but their understanding about antibacterial resistance was only $44 \%$. Majority of participants have self-medication experiences $(86 \%$ and $84 \%$ for paramedics and non-medical staff respectively). Antibiotics were used by both the groups for symptomatic treatment of various clinical conditions without any rationale justifications. The major reason for not visiting medical practitioner was cost saving and convenience (non-medical staff $80 \%$ and paramedics $60 \%$. Antibiotics were mainly obtained from the community pharmacist (non-medical staff $100 \%$ and paramedics $68 \%$ ).

Conclusions: Self-medication practice was prevalent among the participants and lack of up-to-date knowledge was the major areas of concern. Antibiotic awareness should reach every corner of our society for prevention of antibiotic resistance.
\end{abstract}

Keywords: Knowledge, Self-medication, Antibiotic usage

\section{INTRODUCTION}

Medication meaning consumption of medicines for prevention, diagnosis and treatment of various clinical disorders. Correct medication practice is considered when patients' health related problems are discussed with the registered medical practitioner, who puts a diagnosis and prescribes the required drugs. This is usually followed by filling of such prescriptions at the pharmacy by the pharmacist. ${ }^{1}$

Self-medication can be defined as the use of drugs to treat self-diagnosed disorders or symptoms, or the intermittent or continued use of a prescribed drug for chronic or recurrent disease or symptoms. WHO defines as "Selfmedication is the selection and use of medicines by individuals to treat self -recognized illness or symptoms". Self-medication includes the use of non-prescription drugs and a range of different alternative medicines such as herbal remedies, food supplements and traditional products home remedies. William Osler said that "a desire to take medicine is perhaps the great feature which distinguishes man from animals". 2 Perhaps selfmedications is an economical option for the treatment of self-limiting illnesses. As the person puts a self-made diagnosis based on the symptoms and buys drug over-the counter to treat it. ${ }^{3}$ But at the same time this could be costly and harmful in the sense that "when a drug is taken means a risk is taken" and with the limited knowledge the damage could be severe. People often do not consult physician when they fall sick. They may either consult a drug store keeper or discuss with the neighbour who may 
have some left over medicines from the previous illnesses. ${ }^{4}$ In our society it is generally observed that peoples whether known or unknown they have a tendency to give their expert opinion when it comes to health related issues. Most of the times whom-ever we meet have an excellent remedy for whatever ails us and this is one of the reasons what compels self-medication practices. Many studies have reported the direct correlation between the misuse of antibiotics and the growing bacterial resistance. ${ }^{4,6,7}$ An incomplete dosage regimen is another area of concern which reflects inadequate patient's knowledge regarding antimicrobial usage.

Ganguly et al (2011) reported antibiotic consumption in India has increased between $6 \%$ and $7 \%$ annually in the past 5 years (from 2005 to 2009). ${ }^{8}$ In India, the practice of self-medication with antibiotics is very common despite of the fact that antibiotics comes under the Schedule H of Indian Drug and cosmetics act 1940, which means that medicines must be sold by retail only when a prescription by registered medical practitioner is produced. Efforts to promote the rational use of drugs have been targeted at the health care services. These efforts started in the 1970s, when the World Health Organization (WHO) introduced the concept of essential drugs which emphasized on the safety, affordability, need and efficacy of the drug.

At present day it is also observed that peoples are highly influenced by the media and the internet which promotes self-medication practices. ${ }^{9}$ This raises the concerns of incorrect self-diagnosis, drug interaction, and use of nonspecific drugs for various disorders per se. ${ }^{10}$ A study conducted at All India Institute of Medical Sciences, New Delhi observed that self-medication was considerably high among undergraduate medical and paramedical students in India and it increased with medical knowledge. ${ }^{11}$ Antibiotics serves as a very important and useful armamentarium in protection against various harmful pathogens. Unfortunately excessive and inappropriate use of antibiotics have resulted in antibiotic resistance which is now a rapidly growing global problem with a strong impact on morbidity and mortality. ${ }^{12-14}$ It is evident that self-medication is a matter of concern worldwide and India is also witnessing a significant rise in inappropriate self-medications practices. ${ }^{15-16}$

Hence, keeping in mind all these problems associated with self-medication of antibiotics we have conducted this study. The idea of this study was to determine the individual's knowledge regarding antibiotics, selfmedication behaviour and attitude towards antibiotic usage among the various groups of people working in a tertiary care hospital. May be with this project we can highlight some of the underlying facts which can help us to understand the problems related to antibiotics and its usages. Since, globally there is a growing concern regarding antibiotic misuse and emergence of resistance.

\section{METHODS}

\section{Study design}

A survey using a validated self-administered questionnaire was conducted in January- February 2016 among the two groups of participants belonging from paramedics and non-medical working staff of PGIMS Rohtak administration. Each participants were provided with questionnaire form, comprising of three parts A, B, and $\mathrm{C}$ consisting of multiple questions along with the corresponding answer options, which he/she feels appropriate to answer. For those who have difficulty in understanding they were explained verbally. They were asked to complete the questionnaire anonymously.

\section{Sample size}

The questionnaire was distributed among 100 candidates, 50 from each group working in various departments of PGIMS Rohtak administration.

\section{Development of questionnaire}

The questionnaire was adapted from previous studies and modified accordingly to suit the conduct of the study. A Questionnaire under heading PART A, PART B, and PART C was designed in order to access or to obtain data regarding knowledge, self-medication behaviour and attitude towards antibiotics usages respectively.

\section{Data analysis}

The questions in the PART A and PART B of the questionnaire were designed to access the knowledge and self-medication behaviour with antibiotics. The participants were assessed by set of response using yes, no and unknown according to which the percentage calculation was tabulated. PART $\mathrm{C}$ questions are intended to study the attitude of the participants regarding antibiotic usage.

\section{RESULTS}

A total of 100 participants (50 from the paramedical staff and 50 from administrative staff) have participated in this study. Responding to the first question of Part A of the questionnaire as shown in Table 1 which constitutes knowledge regarding antibiotics, the study data revealed that all of the paramedic participants were aware of the term antibiotics. Among non-medical respondents $86 \%$ were aware of the term, $12 \%$ were unaware followed by $2 \%$ who were uncertain. This shows that, although the participating candidates belong to different working backgrounds but they were mostly aware of the term antibiotics.

Referring to the question whether antibiotics are commonly used to treat all kind of infections irrespective of bacterial and viral origin; $46 \%$ of paramedic respondents opted yes followed by $50 \%$ no and $4 \%$ 
uncertain. Among the non-medical staff $46 \%$ responded yes which is equivalent to the paramedic group, followed by $28 \%$ no and $26 \%$ uncertain. This figure shows that more than $50 \%$ of the participants from both the groups have limited knowledge regarding the kind of infection that can be treated with antibiotics. Ineffective treatment has always been a major health concern. Paramedic respondents $(68 \%)$ were aware that indiscriminate and injudicious antimicrobial usage can cause ineffective treatment. But $18 \%$ do not think this statement to be true followed by $14 \%$ respondents who do not have any answer. On the other hand $78 \%$ non-medical respondents were aware of this statement, but $6 \%$ were not aware followed by $16 \%$ with uncertainty. The percentage difference between the two groups show that no matter paramedics have more exposure to the medical knowledge but still there is inadequacy in understanding the problem.

Antibiotic resistance is the major area of concern at present time. All the paramedics were aware of the term antibiotic resistance. But very few percentage of nonmedical respondents were aware of it, only $44 \%$ only $44 \%$ have heard of it, while have heard of it while $32 \%$ have no idea and $24 \%$ were uncertain about it. This shows that there is serious lacking of knowledge among the common people, which is an alarming signal for approaching problem of antibiotic resistance.

Table 1: Knowledge regarding antibiotics and its resistance.

\begin{tabular}{|c|c|c|c|c|c|c|c|}
\hline \multirow[b]{2}{*}{$\begin{array}{l}\text { Q. } \\
\text { No. }\end{array}$} & \multirow[b]{2}{*}{ Questions } & \multicolumn{2}{|l|}{ Yes N (\%) } & \multicolumn{2}{|l|}{ No $\mathbf{N}(\%)$} & \multicolumn{2}{|c|}{ Uncertain $N(\%)$} \\
\hline & & Paramedics & $\begin{array}{l}\text { Non- } \\
\text { medicos }\end{array}$ & Paramedics & $\begin{array}{l}\text { Non- } \\
\text { medicos }\end{array}$ & Paramedics & $\begin{array}{l}\text { Non- } \\
\text { medicos }\end{array}$ \\
\hline 1 & $\begin{array}{l}\text { Do you know what antibiotics } \\
\text { are? }\end{array}$ & $100 \%$ & $86 \%$ & Nil & $12 \%$ & Nil & $2 \%$ \\
\hline 2 & $\begin{array}{l}\text { Antibiotics are commonly } \\
\text { used to treat all kind of } \\
\text { infections whether Bacterial } \\
\text { or viral }\end{array}$ & $46 \%$ & $46 \%$ & $50 \%$ & $28 \%$ & $4 \%$ & $26 \%$ \\
\hline 3 & $\begin{array}{l}\text { Ineffective treatment can } \\
\text { occur due to indiscriminate } \\
\text { and injudicious antimicrobial } \\
\text { use }\end{array}$ & $68 \%$ & $78 \%$ & $18 \%$ & $6 \%$ & $14 \%$ & $16 \%$ \\
\hline 4 & $\begin{array}{l}\text { Have you heard about } \\
\text { antibiotic resistance? }\end{array}$ & $100 \%$ & $44 \%$ & Nil & $32 \%$ & Nil & $24 \%$ \\
\hline 5 & $\begin{array}{l}\text { Indiscriminate antimicrobial } \\
\text { use leads to the emergence of } \\
\text { the growing problem of } \\
\text { resistance }\end{array}$ & $76 \%$ & $30 \%$ & $4 \%$ & $2 \%$ & $20 \%$ & $68 \%$ \\
\hline
\end{tabular}

Table 2: Self-medication behaviour.

\begin{tabular}{|c|c|c|c|c|c|c|c|}
\hline & Questions & Yes N (\%) & & No $\mathbf{N}(\%)$ & & Uncertain I & $\%)$ \\
\hline $\begin{array}{l}\text { Q. } \\
\text { No. }\end{array}$ & & Paramedics & $\begin{array}{l}\text { Non- } \\
\text { medicos }\end{array}$ & Paramedics & $\begin{array}{l}\text { Non- } \\
\text { medicos }\end{array}$ & Paramedics & $\begin{array}{l}\text { Non- } \\
\text { medicos }\end{array}$ \\
\hline 1 & $\begin{array}{l}\text { Have you ever treated (self- } \\
\text { medicated) with antibiotics? }\end{array}$ & $86 \%$ & $84 \%$ & $14 \%$ & $12 \%$ & Nil & $4 \%$ \\
\hline 2 & $\begin{array}{l}\text { Did you check the } \\
\text { instructions come with the } \\
\text { package insert of antibiotics } \\
\text { for self-treatment? }\end{array}$ & $60 \%$ & $32 \%$ & $36 \%$ & $56 \%$ & $4 \%$ & $12 \%$ \\
\hline 3 & $\begin{array}{l}\text { Did you change the dosage of } \\
\text { antibiotics deliberately } \\
\text { during the course of self- } \\
\text { treatment? }\end{array}$ & $24 \%$ & $8 \%$ & $72 \%$ & $80 \%$ & $4 \%$ & $12 \%$ \\
\hline 4 & $\begin{array}{l}\text { Did you ever switch } \\
\text { antibiotics during the course } \\
\text { of self-treatment? }\end{array}$ & $22 \%$ & $18 \%$ & $66 \%$ & $68 \%$ & $12 \%$ & $14 \%$ \\
\hline 5 & $\begin{array}{l}\text { What do you think self- } \\
\text { medication with antibiotics is } \\
\text { a good practice? }\end{array}$ & $12 \%$ & $20 \%$ & $76 \%$ & $78 \%$ & $12 \%$ & $2 \%$ \\
\hline
\end{tabular}


Table 3: Attitude towards antibiotic usages.

\begin{tabular}{|c|c|c|c|}
\hline Sl. No. & Questions & \multirow[b]{2}{*}{$\begin{array}{l}\text { Paramedics } \\
\mathbf{N}(\%)\end{array}$} & \multirow[b]{2}{*}{$\begin{array}{l}\text { Non- medicos } \\
\text { N(\%) }\end{array}$} \\
\hline \multirow{11}{*}{1.} & $\begin{array}{l}\text { For which of the following complaint(s) did you use antibiotics? } \\
\text { (check more than one if applicable) }\end{array}$ & & \\
\hline & A. Runny nose & 34 & ------- \\
\hline & B. Nasal congestion & 18 & 10 \\
\hline & C. Cough & 42 & 60 \\
\hline & D. Sore throat & 38 & 4 \\
\hline & E. Fever & 26 & 34 \\
\hline & F. Aches and pains & 12 & 2 \\
\hline & G. Vomiting & 24 & ------- \\
\hline & H. Diarrhea & 28 & 42 \\
\hline & I. Skin wounds & 30 & 2 \\
\hline & J. Others (specify) & ------- & $\begin{array}{l}\text { *Dental infection } \\
\text { *Skin infection }\end{array}$ \\
\hline \multirow{5}{*}{2.} & $\begin{array}{l}\text { What was (were) your reason(s) of self-medication with } \\
\text { antibiotics? (check more than one if applicable) }\end{array}$ & & \\
\hline & A. Cost saving & 8 & 20 \\
\hline & B. Convenience & 60 & 80 \\
\hline & C. Lack of trust in prescribing doctor & ------- & 2 \\
\hline & D. Others (specify) & ------- & $\begin{array}{l}\text { *To save time } \\
* \text { Via phone calls } \\
\text { to doctor }\end{array}$ \\
\hline \multirow{8}{*}{3} & $\begin{array}{l}\text { Your selection of antibiotics was based on... (check more than one } \\
\text { if applicable) }\end{array}$ & & \\
\hline & A. Recommendation by community pharmacists & 36 & 16 \\
\hline & B. Opinion of family members & 6 & 32 \\
\hline & C. Opinion of friends & 4 & 6 \\
\hline & D. My own experience & 28 & 40 \\
\hline & E. Recommendation by net citizens & 2 & ------ \\
\hline & F. Previous doctor's prescription & 58 & 34 \\
\hline & G. The advertisement & 4 & ------ \\
\hline \multirow{6}{*}{4} & $\begin{array}{l}\text { Where did you usually obtain antibiotics from for self- } \\
\text { medication? (check more than one if applicable) }\end{array}$ & & \\
\hline & A. Community pharmacies & 68 & 100 \\
\hline & B. Traditional medical practitioners & 18 & ------ \\
\hline & C. Leftover from previous prescription & 10 & 6 \\
\hline & D. Online shopping/E-pharmacies & 2 & ------ \\
\hline & E. Others (specify) & ------ & ------ \\
\hline \multirow{8}{*}{5.} & $\begin{array}{l}\text { When did you normally stop taking antibiotics? (check more than } \\
\text { one if applicable) }\end{array}$ & & \\
\hline & A. After a few days regardless of the outcome & 10 & ------ \\
\hline & B. After symptoms disappeared & 34 & 74 \\
\hline & C. A few days after the recovery & 12 & 8 \\
\hline & D. After antibiotics ran out & ------ & ------ \\
\hline & E. At the completion of the course & 26 & 18 \\
\hline & F. After consulting a doctor/pharmacist & 8 & ------ \\
\hline & G. Others (specify) & ------ & ------ \\
\hline
\end{tabular}

$76 \%$ of paramedics have an opinion that indiscriminate antimicrobial use can leads to the emergence of the growing problem of resistance with $4 \%$ who do not think so and rest $20 \%$ were uncertain. Among non-medical respondents $30 \%$ of participants have also correlated indiscriminate antimicrobial use with emergence of resistance, while $2 \%$ have different opinions while majority of them i.e. $68 \%$ have uncertainty in their opinions. Part B of questionnaire as given in Table 2 was about self-medication behavior among the participants. Most of the paramedics around $86 \%$ of the participants have a history of self-medication with antibiotics and rest 
$14 \%$ do not have. On the other hand $84 \%$ of administrative respondents have also positive history of self-medication, with $12 \%$ who do not have, followed by $4 \%$ who do not remember. This shows that in majority of participants self-medication is a part of life. In order to deal with the irrational antibiotic self-medication practice, package inserts are provided with the medicine which includes all the relevant information regarding that particular medicine and it is the basic duty of every citizen to carefully read it before consumption of any medicine. But data revealed only $60 \%$ of paramedics and $32 \%$ non-medical respondents check the instruction that comes with the package insert. While rest of the participants from both the groups either do not read or they were uncertain about it. This shows that most of the participants were unaware of the utility of package inserts and its significance. Also the dosage of antibiotics was deliberately changed by $24 \%$ of paramedics and $8 \%$ of non-medicos during the course of self-treatment. However majority of participants from both the groups (paramedics $72 \%$ and administrative staff $80 \%$ ) do not change, while rests of the respondents were uncertain. Participants had also switched over to different antibiotics during the course of self-treatment, figure turns out to be $22 \%$ and $18 \%$ for paramedics and nonmedicos respectively. While $66 \%$ paramedics and $68 \%$ non-medical respondents do not change to different antibiotics at the time of self-medication with rest of respondents who were uncertain. No matter small percentage of participants from both the groups have a practice of switching over to different antibiotics during the period of self-medication, but it could give a significant rise in antibiotic resistance and may also result in spreading of harmful pathogen.

$12 \%$ paramedics and $20 \%$ non-medical respondents do believe that self-medication is a good practice while on the other hand $76 \%$ of paramedics and $78 \%$ of nonmedical respondents do not think so and remaining from both the groups were uncertain.

Part $\mathrm{C}$ of the questionnaire as given in Table-3 represented individual's attitude toward antibiotic usage. Data revealed that the most common symptoms for antibiotic usage among paramedics included cough followed by sore throat, runny nose, skin wounds, diarrhoea, fever, vomiting, nasal congestion and pain. On the other hand non-medicos have mainly used antibiotics for cough, diarrhoea, fever, nasal congestion, dental infection and skin infections. It showed that antibiotic usage was irrational as influenza, common cold are selflimiting and need no antibiotic use unless there is a secondary bacterial infection. The most common reason for self-medication among the participants was convenience. $60 \%$ of the paramedics responded that convenience was the main reason for self-medication, followed by $6 \%$ who opted for cost saving reasons. On the other hand $80 \%$ of the non-medical respondents have also considered convenience as the major factor followed by cost savings i.e. $20 \%$, lack of thrust on doctors $2 \%$.
Others reasons mentioned by both the groups were time savings and consultation via phone calls to the doctor. Study data also revealed that selection of antibiotics was based on several reasons. Paramedic's criteria for selection was mostly based on previous doctor's prescription $58 \%$, followed by recommendation by the community pharmacist $36 \%$, their own experiences $28 \%$, others included opinion of family members $6 \%$, opinion of friends and from advertisements $4 \%$, recommendation by the net citizens $2 \%$. Selection criteria for non-medicos was mainly based on their experiences $40 \%$, family member's opinion $32 \%$, previous doctor's prescription $34 \%$, recommendation by the community pharmacist $16 \%$, opinion of the friends $6 \%$. The antibiotics for selfmedication practice were generally obtained from different sources. $68 \%$ of paramedics have obtained from the community pharmacist, $18 \%$ from community medical practitioners, $10 \%$ from previous antibiotic left over and $2 \%$ from e-pharmacies. On the other hand $100 \%$ of non-medical staff have mostly obtained from the community pharmacist and $6 \%$ out of them have also used from the previous leftovers. The stopping criteria for antibiotic usage among the respondents were different, $34 \%$ of the paramedics generally stop antibiotics after the symptoms disappeared, $26 \%$ at the completion of course, $12 \%$ few days after the recovery, $10 \%$ after few days regardless of the outcome, $8 \%$ after consulting a doctor/pharmacist. While $74 \%$ non-medical respondents stopped the antibiotic after the symptoms disappeared, $18 \%$ after the completion of the course, $8 \%$ a few days after the recovery. It clearly shows that proper antibiotic regimen was not followed for its optimal utility which could have significant negative impact.

\section{DISCUSSION}

The emergence of bacterial strains resistant to antimicrobial agents presents a growing concern worldwide. Irrational use of antibiotics has contributed to the progressive loss of bacterial sensitivity to antibiotics and spreading of resistant strains of bacteria, with substantial clinical and economic impact. ${ }^{17}$ The effectiveness of antibiotics depends on their correct use, depending on patients, physicians and retailers. ${ }^{18}$

Patient factors relating to incorrect antibiotic use are multifactorial which include self-medication, sharing medication with other people, not taking a full course of treatment and keeping part of the course for another occasion. Despite of the Indian antimicrobial policy under schedule H of Drug and Cosmetic Act 1940, which restrict the dispensation of antibiotics without prescription, our result indicated the wide availability of antibiotics without proper prescription. Antibiotics were used by more than $80 \%$ of our study population. In India the prevalence of self- medication with antimicrobial agents varies from 24 to $67 \% .^{25}$ Multifactorial reasons contribute to high prevalence of self-medication like culture, nature of the rural Indian population, illiteracy, lack of guidance and awareness. In India when it comes 
to health related issues every neighbor becomes a medicine prescriber with their suggestions. This may lead to polypharmacy and may end up with serious consequences. Factors like traditional, social and cultural belief may also influence self-medication practices. Another contributing factor is the ease with which antibiotics can be acquired from the community pharmacies, due to lack of high disciplinary regulations. The antimicrobial policies in the India comprise no distinct clauses or articles that stipulate any sort of punitive procedures or punishments for dispensing antibiotics without medical prescriptions.

In this study $100 \%$ of paramedic participants were aware of the term antimicrobials and antimicrobial resistance. But overall knowledge regarding the kind of infection it can treat whether bacterial or viral, and the cause for the emergence of resistance seems to be less. While on the other hand non-medical respondents from various departments have shown very limited knowledge. About $86 \%$ participants are aware of the term antibiotics and but only $44 \%$ have heard about the term resistance. It was also seen that majority of the study participants consider self-medication not a good practice, but ironically most of them have experienced self-medication with antibiotics.

Approximately $85 \%$ of participants had an experience of self-medication with antibiotics the reason being convenience followed by cost saving, time saving, consulting known physician via phone calls. Selfmedication appears to be more driven by convenience factor followed by economic factor. It is known fact that in India medical resources are limited as per the growing population is concerned; we still have limited number of physicians and paramedical staffs. It is difficult for every individual to wait in a long queue and go frequent follow ups, while others cannot afford private medical practitioner. Therefore, the medical services should be made convenient for patients in terms of waiting periods, as delay in service at hospitals/clinics was another major factor associated with self-medication. Providing affordable medical services may be crucial for dealing with the problem of irrational antibiotic usage.

While taking medicines whether prescribed or nonprescribed it is also the basic duty of the consumer to read the package inserts. Our study revealed only $60 \%$ of paramedics and $32 \%$ of non-medicals check the instructions that come with the package inserts of antibiotics. Package inserts provides an essential tool for extracting the basic knowledge for understanding the drug for its optimal utility. ${ }^{19}$ However in terms of antibiotic dosage and switching of antibiotics majority of participants did not change the dose and switch over to another antibiotics during the course of treatment.

Conditions such as common cold, cough, fever, diarrhea, sore throat, skin infection were commonly treated with antibiotics by the study participants. Influenza and common cold are self-limiting and need no antibiotic use unless there is a secondary bacterial infection. While others like cough could be as a result of multiple etiologies like tuberculosis etc. therefore use of antibiotics in such condition can mask the underlying cause. In the same way diarrhea is also a symptom which could have multiple etiologies as well. $46 \%$ of our study participants also believe that antibiotics can treat and eradicate any infections irrespective of their origin. It also revealed that the participants were unaware of the dangers and consequences of inappropriate use of antibiotics. Another similar study has reported that more than $60 \%$ of the participants believed that antibiotics should be prescribed for viral illnesses assuming bacterial etiology. $^{20}$ Such wrong beliefs may lead to inappropriately high rates of antibiotic consumption, which can result in a corresponding increase in the bacterial resistance. From the results it was also observed that the selection of antibiotics for self-medication was not only based on their own past experiences but also recommendation from various sources like community pharmacist, friends, family members, senior citizens, and previous doctor's prescription. Mostly the antibiotics are obtained from the pharmacists. Therefore the community pharmacists should acquire higher level of knowledge and skills since they are frequently in touch with the consumers. They should exhibit their willingness to involve themselves in the patient's drug therapy and must develop close working relationship with other health care professionals.

Our study data also revealed that as soon as the symptoms disappeared the patients stopped taking antibiotics without the completion of full treatment course. This could trigger serious consequences because symptoms are as a result of underlying cause and killing these symptoms may not necessarily heal the body from disease. More over incomplete course regimen may result in provocation of resistance and emergence of superbugs. A major problem with self-medication with antibiotics is the emergence of drug resistance. Antimicrobial resistance is a current problem worldwide particularly in developing countries. Evidence from various studies indicated that self-medication appears to be relatively higher in the developing countries. ${ }^{21}$ It is widely believed that human malpractices such as inadequate dosing, incomplete courses and indiscriminate drug use have contributed to the emergence and spread of antimicrobial resistance. So the consequence could be loss of relatively cheaper antibiotics available till date, and colossal expenditure for newer drug development. The rational use of antibiotics is thus an utmost importance to limit the increase in bacterial resistance. Consumers are required to understand the magnitude of this problem with regards to the potential benefits as well as risks associated with irrational use and show willingness to equally participate in combating this problem. Our findings indicated the need for the establishment of proper guidelines for sale of antibiotics. The study showed that more than $50 \%$ of the study respondents do not complete an antibiotic course 
which is alarming in the light of behavioral practices that promote antibiotic resistance. Antibiotic resistance has been attributed to misuse and overuse of antibiotics which puts selective pressure on bacterial pathogens leading to the emergence and spread of resistance. ${ }^{21-22}$ The enforcement of antibiotic policies in our country should be with cautions as there are limited number physicians in country side, poor people may always not be able to visit physician. Strict prescription policy might rather exclude the poor from accessing the drugs at the required time, resulting in increased morbidity from otherwise treatable infections. In the light of this, it appears that a good strategy in the short term can be achieved by providing education through health camps, seminars etc. Every citizen should be made aware of the problems related to self-medication practices. At the institution level more and more awareness program should be organized to spread the basic knowledge of do and don'ts.

These study findings are based on a single centre study in PGIMS Rohtak; therefore observations cannot be generalized per se. More multi-centric studies are needed to the carried out among the students and general population to understand the various factors influencing the practice of self-medication in India. The role of socioeconomic status and its influence on practice of selfmedication needs to be explored in future studies.

Our study provides an important insight regarding the knowledge, behaviour and attitudes towards antibiotic usages among the paramedics and non-medicos in an institution. The medical education strategies should aim, not only to increase the knowledge, but also to change the behaviour and practices among the peoples.

\section{CONCLUSION}

The practice of self-medication with antibiotics was prevalent among the study participants. Lack of up-todate knowledge regarding antibiotic usage was identified as one of the major areas of concern. Inappropriate use of antibiotics without the prescription of registered medical practitioner is not justified and is also one of the major causes of antibiotic resistance. Hence there is a need to increase the awareness regarding antibiotic usage across the community for better outcomes.

Funding: No funding sources

Conflict of interest: None declared

Ethical approval: The study was approved by the Institutional Ethics Committee

\section{REFERENCES}

1. Femi-Oyewo MN, Adejumo OE, Hassan SA. Self medication pattern among students of olabisi onabanjo University, ogun State. Nig. J. Pharm. 2002;1(1):17-20.
2. Phalke VD, Phalke DB, Durgawale PM. Selfmedication practices in rural Maharashtra. Indian J Community Med. 2006;31:34-5.

3. World Health Organization (2000) Guidelines for the regulatory assessmentof medicinal products for use in self-medication. WHO/EDM/QSM/00.1.

4. Bronzwaer SL, Cars O, Buchholz U. A European study on the relationship between antimicrobial use and antimicrobial resistance. Emerg Infect Dis. 2002;8:278-82.

5. Bauchner H, Pelton SI, Klein JO. Parents, physicians, and antibiotic use. Pediatrics. 1999;103:395-401.

6. Seppala H, Klaukka T, Vuopio-Varkila J, Muotiala A, Helenius H, Lager K, et al. The effect of changes in the consumption of macrolide antibiotics on erythromycin resistance in group A streptococci in Finland. Finnish study group for antimicrobial resistance. N Engl J Med. 1997;337:441-6.

7. Austin DJ, Kristinsson KG, Anderson RM. The relationship between the volume of antimicrobial consumption in human communities and the frequency of resistance. Proc Natl Acad Sci USA. 1999;96:1152-6.

8. Ehigiator O, Azodo CC, Ehizele AO, Ezeja EB, Ehigiator L. Self-medication practices among dental, midwifery and nursing students. Eur J Gen Dentistry. 2013;2:54-7.

9. Klemenc-Ketis Z, Hladnik Z, Kersnik J. A cross sectional study of sex differences in self-medication practices among university students in Slovenia. Coll Antropol. 2011;35(2):329-34.

10. Burak LJ, Damico A. College students' use of widely advertised medications. J Am Coll Health. 2000;49(3):118-21.

11. Self-medication popular among medical students: AIIMS study. Available: http://www.livemint.com/ Politics/XcN44QD5g8aW4dwltcUdtI/. Accessed on 01 August 2016.

12. Spellberg B, Guidos R, Gilbert D. for the infectious Diseases Society of America. The epidemic of antibiotic-resistant infections: a call to action for the medical community from the Infectious Diseases Society of America. Clin Infect Dis. 2008;46(2):155-64.

13. Sarkar P, Gould IM. Antimicrobial agents are societal drugs: how should this influence prescribing? Drugs. 2006;66(7):893-901.

14. Levy SB. Antibiotic resistance-the problem intensifies. Advanced Drug Delivery Reviews. 2005;57(10);1446-50.

15. Saradamma RD, Higginbotham N, Nichter $M$ : Social factors influencing the acquisition of Antibiotics without prescription in Kerala State, south India. Soc Sci Med. 2000;50(6):891-903.

16. Otoom S, Sequeira RP. The respondents' knowledge about appropriate self-medication was poor, but knowledge. www.ncbi.nlm.nih.gov/pubmed/167633 93. 
17. Maragakis LL, Perencevich EN, Cosgrove SE: Clinical and economic burden of antimicrobial resistance. Expert Rev Anti Infect Ther. 2008;6:75163.

18. Radyowijati A, Haak $\mathrm{H}$ : Determinants of antimicrobial use in the developing world. In Child Health Special Report.Washington, DC: USAID Bureau of Global Health; 2002.

19. Narzaree P, Gupta MC. A critical appraisal of medication package inserts. Int $\mathrm{J}$ Pharmacol Res. 2015;5(10):226-30.

20. Steinberg I. Clinical Choices of Antibiotics: Judging Judicious Use. The American Journal of Managed Care. 2000;6(23):1178-88.
21. Vila J, Pal T. Update on antibacterial resistance in low-income countries: Factors favouring the emergence of resistance. Open Infect. Dis. J. 2010;4:38-54.

22. Harbarth S, Samore MH. Antimicrobial resistance determinants and future control. Emerg. Infect. Dis. 2005:11;794-801.

Cite this article as: Narzaree $\mathrm{P}$, Gupta MC. Knowledge towards antibiotic usage among paramedics and non-medical personnels of a tertiary care hospital. Int J Basic Clin Pharmacol 2016;5:1929-36. 